\title{
Rewolucji rosyjskiej rok pierwszy. Wybrane zagadnienia prawa karnego
}

1 Rewolucja lutowa, zniknięcie dynastii, którą od dwóch wieków, a więc „od zawsze", utożsamiano z samodzierżawiem, centralizmem, brakiem wolności obywatelskich, wywołało efekt lawinowy w zakresie zmian tego wszystkiego, co było przed abdykacją Mikołaja II. Rząd Tymczasowy mógł się jawić myślącej opinii publicznej, zwłaszcza stolicy i kręgów wojskowych, jako rząd rewolucyjny, mimo że aż do lipca 1917 r. dominowali w nim konstytucyjni demokraci (kadeci ${ }^{1}$ ), partia liberalna, ale o nader umiarkowanym programie. Początkowo rząd cieszył się dużym uznaniem inteligencji i ludzi politycznie aktywnych; szybko został też uznany na arenie międzynarodowej. Był jednak Rząd Tymczasowy faktycznie wielce ograniczony i kontrolowany przez Radę Piotrogrodzką, która działała sprawniej i miała - w przeciwieństwie do niego - chociaż częściowo narzędzia niezbędne do realizacji swoich decyzji. Żadnej z tych dwu władz nie przychodziło na myśl, by rozgraniczyć obszary swej działalności, a zwłaszcza Monteskiuszowskim podziałem władzy nikt sobie głowy nie zaprzątał w kraju, który właśnie odszedł od rządów absolutnych. Obie stołeczne instytucje sprawowały władzę zarówno ustawodawcza, jak i wykonawczą; jedynie sądy funkcjonowały odrębnie. Rząd Tymczasowy wydawał wiele ustaw i rzec trzeba, że doty-

${ }^{1}$ Konstytucyjni demokraci, kadeci; Partia Konstytucyjno-Demokratyczna, od 1906 r. Partia Wolności Ludu; utworzona w X 1905, zwana partią liberałów rosyjskich; skupiała głównie inteligencję i liberalną szlachtę; program przewidywał wprowadzenie w Rosji monarchii konstytucyjnej; po rewolucji lutowej opowiedzieli się za ustrojem republikańskim; mieli w programie dokonanie ograniczonej reformy rolnej; posłowie konstytucyjnych demokratów wchodzili do wszystkich czterech Dum Państwowych (1905-1907); w czasie I wojny głosili hasło walki aż do zwycięstwa; po bolszewickim zamachu stanu opowiedzieli się przeciwko bolszewikom, a ci ogłosili ich wrogami ludu i represjonowali, por. w: Leksykon historii świata: Rosja, red. W. Sienkiewicz, Warszawa 2001, s. 139. 
czyły one spraw ważnych, na ogół nieznanych w państwie carów²: zniesiono wszelkie ograniczenia praw obywatelskich z uwagi na wyznanie albo narodowość, pełne prawa otrzymali m.in. żołnierze; proklamowano wolność zgromadzeń i stowarzyszeń; Polsce i Finlandii obiecano ważne zmiany w ich statusie.

W tym samym nurcie rozdawania uprawnień i ogólnej liberalizacji widzieć trzeba decyzję rządu z 25 marca 1917 r. o całkowitym zniesieniu kary śmierci. W warunkach wojny i znacznego rozprężenia w kraju decyzja to zaiste zaskakująca. W istocie naiwna w swoim utopijnym charakterze, w przekonaniu iż "teraz wszystko będzie dobrze". Będzie tej sprawy ciąg dalszy, ale trzymajmy się choć trochę chronologii wydarzeń. Kraj pogrążał się coraz bardziej w chaosie gospodarczym i politycznym. W stolicy brakowało żywności. Armia znajdowała się w stanie niebywałego rozkładu. Czerwcowa ofensywa roku 1917, podjęta wszak głównie dla poprawienia morale wojska, a zakończona kompromitującą klęską i pokazem moralnego upadku armii (głównie mas żołnierskich), jej ducha bojowego, nie mogła pozostać bez skutków w kraju. Z rządu ustąpili ministrowie kadeccy. Narastający ferment społeczny, w tym w wojsku, mnożące się strajki i coraz częściej pojawiające się żądania oddania władzy radom, wydawały się stanowić dobrą glebę dla pogłębienia społecznej demoralizacji i podjęcia próby zamachu stanu. Zdecydowali się na to - mimo wahan - bolszewicy, ale nie udało się. Kiedy (20 lipca 1917 r.) po dymisji księcia Lwowa obowiązki premiera przejął Aleksandr Fiodorowicz Kiereński, ten socjalista (eserowiec) - wydaje się - był chyba jednak niezdecydowany, kogo należy obawiać się bardziej: bolszewików czy monarchistów, zamachu na lewicy czy na prawicy. W istocie groziły oba. Początkowo nowy premier wydawał się skłaniać do lansowanej w niektórych kołach politycznych koncepcji uzdrowienia sytuacji w drodze użycia siły wojskowej. Kręgi te reprezentował generał Ławr Gieorgijewicz Korniłow ${ }^{3}$, głównodowodzący całości rosyjskich sił zbrojnych. Warto zwrócić

${ }^{2}$ Tekst polski deklaracji Rządu Tymczasowego o jego składzie i zadaniach z 3 III 1917 r. zob. m.in. Historia państwa i prawa. Wybór tekstów źródtowych, red. B. Lesiński, Poznań 1995, s. 258-259.

${ }^{3}$ Ławr Gieorgijewicz Korniłow (1870-1918), urodził się koło Karagandy (Kazachstan) jako syn oficera, pochodził z rodziny kozackiej, absolwent szkoły artylerii i Akademii Sztabu Generalnego, znał języki turecki, perski, chiński; uczestnik wojny rosyjsko-japońskiej (1904-1905); attaché wojskowy w Chinach; w czasie I wojny dowódca dywizji, potem korpusu; ranny trafił do niewoli austriackiej, z której brawurowo uciekł, co przydało mu popularności; po rewolucji lutowej dowódca piotrogrodzkiego okręgu wojskowego, odpowiedzialny za ochronę rodziny byłego cara; 19 VII (1 VIII) 1917 r. mianowany naczelnym wodzem całości sił rosyjskich; w czasie ofensywy w VI 1917 r. w obliczu panicznej ucieczki całych oddziałów rosyjskich zażądał przywrócenia przez rząd kary śmierci na 
w tym miejscu uwagę, że to Korniłow w czerwcu roku 1917 - w obliczu klęski armii na froncie i panicznej ucieczki zrewoltowanych oddziałów - postanowił wprowadzić karę śmierci na froncie, co zaakceptował rząd (25 lipca).

Ministrem wojny w rządzie Kiereńskiego był wówczas eserowiec, słynny były terrorysta Borys Wiktorowicz Sawinkow ${ }^{4}$; Sawinkowa osobi-

froncie, co uzyskał; jako jedyny z carskich generałów prezentował poglądy demokratyczne, co wydawało się do zaakceptowania dla Rządu Tymczasowego i w jakimś porozumieniu z Kiereńskim, w celu „opanowania w Rosji anarchii”, wysłał siły wojskowe do spacyfikowania stolicy z jej zdemoralizowanym dużym garnizonem, ale premier rządu wycofał się z ustaleń i pucz się nie udał, Korniłow zaś został na polecenie rządu aresztowany; po zamachu bolszewickim zbiegł (XII 1917) z aresztu i udał się nad Don; był jednym z organizatorów i głównodowodzącym Armii Ochotniczej na południu Rosji, głównej wojskowej formacji białych; zginął w czasie szturmu na Jekatierinodar. J. Smaga [w:] G. Przebinda, J. Smaga, Kto jest kim w Rosji po 1917 roku, Kraków 2000; Wielka encyklopedia powszechna PWN [dalej: WEP]; A. Kijas [w:] Leksykon historii powszechnej 1900-1945, red. S. Sierpowski przy współpracy S. Żerki, Poznań 1996; P. Wieczorkiewicz [w:] L. Bazylow, Historia Rosji, Wrocław-Warszawa-Kraków 2005, s. 382.

${ }^{4}$ Borys Wiktorowicz Sawinkow (1879-1925), urodził się w Charkowie w rodzinie prokuratora wojskowego, po roku 1881 ojciec jego przeniesiony został do Warszawy na stanowisko sędziego; Borys uczył się w Warszawie, studiował kulturę i historię Polski, mówił dobrze po polsku; nawiązał kontakty z Polską Partią Socjalistyczną; studia rozpoczął na wydziale prawa uniwersytetu w Petersburgu, po dwóch latach relegowany za działalność polityczną (poparł studentów Warszawy protestujących przeciwko odsłonięciu pomnika Michaiła Murawjowa-Wieszatiela); studia kontynuował w Berlinie i Heidelbergu; wykształcony, inteligentny, o wybitnych zdolnościach organizacyjnych; w $1900 \mathrm{r}$. wrócił do Rosji; pisał o konieczności wykształcenia zawodowej elity rewolucjonistów; w 1903 r. zbiegł za granicę i w Genewie poznał Jewno Azefa, który w tym czasie stanął na czele Wydziału Bojowego Partii Socjalistów-Rewolucjonistów [S-R; eserowcy] (jak się później, w 1908 r. okazało - był on jednocześnie agentem Ochrany); wspólnie z Azefem dokonał zamachu na ministra spraw wewnętrznych Wiaczesława Plehwego (zabity w 1904 r.), uczestniczył w zamachach na wielkiego księcia Sergiusza - generała-gubernatora Moskwy i popa Georgija Gapona (zabici w 1905-1906 r.) i inne; aresztowany w 1906 r. przy nieudanym zamachu, zbiegł z więzienia za granicę; napisał tam główne książki swojego życia dotyczące psychologii terroryzmu, a także autobiograficzne, w których m.in. wyraził rozczarowanie słabymi skutkami terroru politycznego; w latach 1914-1917 służył jako ochotnik w armii francuskiej; po rewolucji lutowej wrócił do Rosji i przez Kiereńskiego został mianowany komisarzem Rządu Tymczasowego przy Kwaterze Głównej, od IX 1917 r. ministrem wojny; popierał Korniłowa w czasie podjętej przez niego próby zamachu stanu; w kołach politycznych Piotrogrodu mówiło się o planowanej kolektywnej dyktaturze Korniłowa, Sawinkowa i Kiereńskiego; po upadku puczu Korniłowa został usunięty z Partii S-R.

Porewolucji październikowejstanąłna czele antybolszewickiegoZwiązku Obrony Ojczyzny i Wolności, przygotowywał zamachy na Lenina i Trockiego, agitował wśród chłopów na prowincji; na początku 1918 r. uczestniczył w tworzeniu Armii Ochotniczej na Kubaniu, pod nadzorem Korniłowa, a następnie Denikina; w VII 1918 r. po wybuchu w Moskwie powstania lewicowych eserowców zorganizował antybolszewickie powstania 
ście znał z czasów PPS-owskiej młodości Józef Piłsudski i później-w roku 1920 - zaprosi go do Polski w nadziei pokierowania zjednoczeniem antybolszewickiej opozycji. Kiereński wydawał się początkowo współdziałać z Korniłowem, ale zaniepokojony utratą kontroli zrobił polityczny zwrot i Korniłow został aresztowany. 31 sierpnia/13 września zakończyła się bezkrwawo i żałośnie próba prawicowego zamachu stanu.

Efektem tych wydarzeń było proklamowanie republiki dekretem rządowym (1/14 września 1917) ${ }^{5}$ i kolejny kryzys gabinetowy, zakończony jednak tylko kosmetyczną reorganizacją trzeciego rządu koalicyjnego.

Upadek Korniłowa to kolejna klęska nieudolnego rządu. Jeśli przypomnieć stan kraju, koszmarne klęski na froncie I wojny, niedostatki podstawowych artykułów żywnościowych, wręcz ruina gospodarcza, inflacja która sięgnęła $1000 \%$, to łatwo zrozumieć zarówno rozłam w partii samego premiera - Partii Socjalistów-Rewolucjonistów (eserowców), jak i gwałtownie spadające społeczno-polityczne poparcie dla koalicjantów rządowych i wzrost notowań bolszewików, którzy jako jedyni nie skompromitowali się jeszcze udziałem $\mathrm{w}$ tak nieudolnym rządzie. Przyszedł ich czas.

2. Łatwo zauważyć, że w odróżnieniu od wcześniejszych prób zamachów stanu, udany październikowy (listopadowy) zamach bolszewików niezwłocznie obfitował aktami prawnymi nowej władzy w Piotrogrodzie. I wcale nie chodzi w tym miejscu tylko o trzy "dekrety" wydane w pierwszym dniu po obaleniu poprzedniego rządu. Wszak tzw. dekret o powo-

w Jarosławiu nad Wołga, Muromiu i Rybińsku, po ich zdławieniu i wprowadzeniu przez bolszewików czerwonego terroru organizował grupy terrorystyczne i kierował licznymi akcjami dywersyjnymi; przez Japonię wyemigrował (1919) do Europy, gdzie organizował pomoc dla Kołczaka i Denikina.

W 1920 r. przybył do Warszawy i w kontakcie z Józefem Piłsudskim organizował działalność antybolszewicka; współpracował z organizatorem białej partyzantki na Białorusi - Stanisławem Bułak-Bałachowiczem; w 1921 r. zmuszony do wyjazdu z Polski na skutek noty protestacyjnej rządu radzieckiego; od 1921 w Paryżu, poszukiwał pomocy u Mussoliniego. Agentom OGPU (bezpieki) udało się zwabić go do potajemnego przybycia do ZSRR 16/17 VIII 1924 r. celem rzekomego objęcia przywództwa konspiracyjnej opozycji; aresztowany w VIII $1924 \mathrm{r}$. w Mińsku; przebywał na Łubiance; złamany w śledztwie zeznawał na procesie zgodnie z instrukcjami bezpieki; sąd pod przewodnictwem Wasilija Ulricha skazał go na karę śmierci, zamienioną „za zasługi w walce z caratem” na dziesięć lat pozbawienia wolności; $17 \mathrm{~V} 1925 \mathrm{r}$. według wersji oficjalnej popełnił samobójstwo: „na oczach strażników wypadł” z okna V piętra na Łubiance, prawie na pewno został wyrzucony przez czekistów. M. Smoleń [w:] Encyklopedia białych plam, t. XVI, Radom 2005; G. Przebinda [w:] G. Przebinda, J. Smaga, Kto jest kim w Rosji...; Leksykon historii świata...; A. Kijas [w:] Leksykon historii powszechnej 1900-1945...; B. Urbankowski, Józef Piłsudski marzyciel i strateg, Poznań 2014; A. S. Kowalczyk, Sawinkow, Warszawa 1992.

${ }^{5}$ Tekst polski zob. m.in. Historia państwa i prawa. Wybór tekstów źródłowych, red. B. Lesiński, Poznań 1995, s. 259-260. 
łaniu rządu nowego w miejsce obalonego, wprawdzie o innej nazwie ${ }^{6}$, ale o analogicznej strukturze jak rząd poprzedni, jest najzwyklejszą czynnością dokonujących zamachu stanu. Drugi z dekretów z 26 października/ 8 listopada 1917 r. - tzw. dekret o pokoju aktem prawnym wbrew nazwie bynajmniej nie był, był manifestem politycznym skierowanym do stron wojujących w wojnie światowej. Znaczenia politycznego dla wewnętrznej sytuacji w Rosji nie należy jednak nie doceniać: wszak wszystko, co się do tego momentu w roku 1917 w Rosji wydarzyło, jakoś tam swoje korzenie miało $\mathrm{w}$ wydarzeniach na froncie, w kompletnej klęsce armii, $\mathrm{w}$ masakrze żołnierzy i w rezultacie $\mathrm{w}$ marzeniach o powrocie do domu; dodajmy: marzeniach realizowanych drogą masowych dezercji.

Trzeci z dekretów pierwszego dnia po dokonanym zamachu stanu, to znany, słynny dekret o ziemi. Tym dekretem rozpoczęła się od pierwszych godzin po bolszewickim zamachu stanu i obaleniu Rządu Tymczasowego w nocy 25/26 października/7/8 listopada 1917 r. likwidacja przedrewolucyjnego stanu prawnego, m.in. w zakresie prawa cywilnego: przyjęty wówczas dekret o ziemi konfiskował bez odszkodowania całą wielką własność

${ }^{6}$ We wspomnianym dekrecie II Zjazdu Rad z 8 XI 1917 r. użyto synonimicznie dwóch nazw: "tymczasowy rząd robotniczy i chłopski, który będzie się nazywał Radą Komisarzy Ludowych", История советской конституциии. Сборник документов. 1917-1957, Москва 1957, s. 9. Owa "tymczasowość" mogła tworzyć skojarzenie z kontynuacją rządu Aleksandra Kiereńskiego, ale w dekrecie z 8 XI wyraźnie, już na wstępie, zaznaczono, że tymczasowy charakter rządu robotniczo-chłopskiego tkwi w tym, iż zostaje on powołany dla zarządzania krajem do czasu zwołania Zgromadzenia Konstytucyjnego (до соызва Учредительного Собрания. История советской конституции. Сборник документо 1917-1957..., s. 9). Jak pisał główny uczestnik wydarzeń, Lew Dawidowicz Trocki, to od Lenina wyszła myśl, by rząd bolszewicki nie nazywał się tak samo, jak burżuazyjny. W autobiografii Trocki tak oto kreślił obraz tamtej chwili: „Władza zdobyta, przynajmniej w Piotrogrodzie. Lenin jeszcze nie zdążył zmienić kołnierzyka. W zmęczonej twarzy czuwają Leninowskie oczy [...] Trzeba utworzyć rząd, jest nas tu kilku członków Centralnego Komitetu. Improwizowane posiedzenie w kącie pokoju. Jak się nazwać? - zastanawia się głośno Lenin. Aby tylko nie ministrami: wstrętna, zużyta nazwa. Może komisarzami - proponuję - tylko że teraz zbyt wielu jest komisarzy. Może naczelni komisarze? Nie, „naczelni” źle brzmi. A może „ludowi”? Komisarze ludowi? No cóż, to chyba będzie nieźle - godzi się Lenin. - A rząd jako całość? Rada, naturalnie rada. Rada komisarzy ludowych, co? Rada komisarzy ludowych? - podchwytuje Lenin. To świetnie: okropnie pachnie rewolucją!", L. Trocki, Moje życie. Próba autobiografii. Autoryzowany przekład z rosyjskiego J. Barski i S. Łukomski, Warszawa 1930 [reprint: Warszawa 1990], s. 376. Cytowany poprzednio przekaz Trockiego powtórzył Stuczka w ważnym źródle naszej wiedzy o radzieckich strukturach władzy owych czasów - w swojej Encyklopedii państwa i prawa. П. Стучка, Энцииклопедия государтва и права, t. II, Москва 1930, s. 795. Zob. też A. Lityński, Utworzenie naczelnego organu administracji państwowej RFSRR - Rady Komisarzy Ludowych, "Gdańskie Studia Prawnicze" 2012, t. XXVII: W kregu historii doktryn politycznych i prawnych oraz konstytucjonalizmu. Ksiegga jubileuszowa Profesora Andrzeja Sylwestrzaka, red. D. Szpoper, s. 180-181. 
ziemską wraz z zabudowaniami oraz wszelkim inwentarzem i w ogóle likwidował prywatną własność ziemi. W tym rolniczym, chłopskim kraju nacjonalizacja ziemi oznaczała obalenie fundamentów społecznych, toteż bolszewicka władza w ciągu pierwszych miesięcy 1918 r. potwierdzała ten akt jeszcze trzykrotnie: w Deklaracji praw ludu pracujacego i wyzyskiwanego (12/25 stycznia 1918 r.), w dekrecie o socjalizacji ziemi (6/19 lutego 1918 r.) oraz w Konstytucji z 10 lipca 1918 r. Normy zawarte w tych aktach dotyczyły zresztą nie tylko gruntów rolnych, lecz także lasów, wnętrza ziemi oraz wód. Dekret o ziemi nie realizował bynajmniej bolszewickiego programu nacjonalizacji całej ziemi, lecz wprowadzał w życie program Partii Socjalistów-Rewolucjonistów (eserowców), nieco uzupełniony.

Poza tymi trzema dekretami z pierwszych godzin po udanym zamachu stanu, najbardziej pospieszyli się bolszewicy ze zniesieniem kary śmierci. Stało się to już w dwie doby po aresztowaniu Rządu Tymczasowego; nowa władza (zjazd rad) nie mogła być gorsza od swojej poprzedniczki i karę śmierci zniosła 28 października/10 listopada 1917 r. ${ }^{7}$ Zauważyć warto, że od wybuchu rewolucji w lutym 1917 r. była to już trzecia zmiana w przedmiocie kary najwyższej. Jak wspomniano, karę śmierci po obaleniu caratu najpierw zniósł Rząd Tymczasowy (25 marca 1917 r.), ale przywrócił ją (25 lipca 1917 r.) wobec dezerterów na froncie.

O propagandowym charakterze decyzji bolszewików, podjętej 28 października/10 listopada 1917 r. na II zjeździe rad, przekonywać nikogo nie trzeba; zadawanie śmierci przez całe lata rewolucji miało się dobrze. Inna sprawa, że na ogół komuniści wówczas wierzyli, iż upadek kapitalizmu sam $\mathrm{w}$ sobie będzie skutkował zniknięciem przestępczości ${ }^{8}$. Podobno Lenin oburzał się; miał wykrzykiwać w gniewie: „co za głupota, co za głupota [...] czyżby wyobrażali sobie, że można przeprowadzić rewolucję bez egzekucji? Jest to błąd, niewybaczalna słabość, pacyfistyczne złudzenie" ${ }^{\prime \prime}$. Trocki podaje też, że mimo formalnego zniesienia kary śmierci, na skutek nacisków Lenina, bolszewicy postanowili tę karę stosować, gdy będzie to konieczne.

Wkrótce zresztą śmierć wróci oficjalnie do bogatego katalogu rewolucyjnych kar. Przywrócono ją dekretem Rady Komisarzy Ludowych

${ }^{7}$ Należy sprostować datę podawaną powszechnie w literaturze przedmiotu, jakoby nastąpiło to 8 XI (26 X). Zob. Об отмене смертной казни, СУ РСФСР 1917, No 1, s. 4, 2-e издание.

${ }^{8}$ История отечественного государства и права, част 2, четвертое издане, переработанное и дополненное, авторский коллектив под редакцией О. И. Чистякова, Москва 2006, s. 81.

${ }^{9}$ Cyt. za M. Filar, W stużbie utopii. 73 lata radzieckiego prawa karnego, Toruń 1992, s. 13. 
z 21 lutego 1918 r. ${ }^{10}$, w krytycznym dla Rosji momencie wojny światowej. Ultimatum niemieckie i wznowienie (17 lutego 1918 r.) ofensywy wojsk państw centralnych przy absolutnej bierności żołnierzy rosyjskich, jacy na froncie jeszcze się znajdowali („,armia nie chce walczyć i nikt jej nie zdoła do tego zmusić [...] nasze wojska po prostu uciekały" ${ }^{11}$; brak niemieckiej reakcji na ugodowe depesze Lenina dowodził, że Niemcy zdecydowali się nie tylko zająć Piotrogród, ale obalić rządy bolszewików ${ }^{12}$. „Żeby ostatecznie utrwalić władzę radziecka, trzeba było położyć kres wojnie $^{\prime 13}$. Nowe warunki niemieckie były jeszcze trudniejsze ${ }^{14}$, bo m.in. obejmowały żądanie oddania także terenów zajętych po wznowieniu działań wojennych 17 lutego 1918 r., wycofanie się Rosji z Ukrainy i Finlandii, przeprowadzenie demobilizacji, rozmaite ustępstwa gospodarcze.

21 lutego 1918 r. Lenin napisał zawierający normy karne tekst - apel i niby dekret w jednej postaci - Ojczyzna socjalistyczna w niebezpieczeństwie $^{15}$. Oficjalnie został on uchwalony na posiedzeniu Rady Komisarzy Ludowych tegoż dnia, a opublikowany nazajutrz w gazetach "Prawda” oraz „Izwiestija CIK”. Dekret-apel, dramatyczny w swej treści, ukazał się w momencie rzeczywiście dla bolszewickiej władzy w Rosji, i dla samej Rosji, krytycznym. Resztka armii (żołnierze, którzy jeszcze nie zdezerterowali) nie przedstawiała absolutnie żadnej wartości bojowej, nie była w stanie ani przez chwilę stawiać oporu armii niemieckiej, której do Piotrogrodu było już względnie niedaleko. Dekret-apel Ojczyzna socjalistyczna w niebezpieczeństwie zawierał w pierwszej części lakoniczne propagandowo-publicystyczne nakreślenie sytuacji i zamiarów militaryzmu niemieckiego; dramatyczne stwierdzenie, że "Socjalistyczna Republika Rad znajduje się w największym niebezpieczeństwie" i wezwanie robotników i chłopów do „ofiarnej obrony"; potem następowało wyliczenie niezbędnych praktycznych poczynań i wysiłków. Wszystko „aż do chwili, kiedy powstanie i zwycięży proletariat Niemiec [...]"; wiara w szybką zwycięską rewolucję proletariacka, zwłaszcza w Niemczech, przebijała wyraźnie także $w$ innych dokumentach owych tygodni i miesięcy. Trzecim, ostatnim z haseł, kończącym omawiany dokument, było: „Niech żyje międzynarodowa rewolucja socjalistyczna!"

${ }^{10} \mathrm{Od} 14 \mathrm{II}$ - tj. do przejścia Rosji na nowy kalendarz - podaję daty tylko według nowego, gregoriańskiego kalendarza.

${ }^{11}$ W. Lenin, Dzieła wszystkie, t. XXXV, Warszawa 1988, s. 359, 371.

${ }^{12}$ Zob. m.in. tamże, s. 323.

${ }^{13}$ Historia wszechzwiazkowej komunistycznej partii (bolszewików). Krótki kurs, Warszawa 1948, s. 243.

${ }^{14}$ W. Lenin, Dzieła wszystkie..., s. 354.

${ }^{15}$ Tekst zob. tamże, s. 345-346, 470; zob. też Historia wszechzwiazkowej komunistycznej partii (bolszewików)..., s. 245. 
Dekret nakazywał organizować (kto miał to czynić? rady? Czeka?) bataliony pracy przymusowej, zajmujące się kopaniem okopów pod kierownictwem specjalistów wojskowych. „Do batalionów tych należy wcielić wszystkich zdolnych do pracy członków klasy burżuazyjnej, mężczyzn i kobiety, pod nadzorem czerwonogwardzistów; opornych - rozstrzeliwać". Natomiast „agenci nieprzyjaciela, spekulanci, bandyci, chuligani, agitatorzy kontrrewolucyjni, szpiedzy niemieccy winni być rozstrzeliwani na miejscu przestępstwa". Pisane na bieżąco (21 lub 22 lutego 1918 r.) osobiste notatki Lenina do dekretu Ojczyzna socjalistyczna w niebezpieczeństwie przewidywały nadto śmierć przez rozstrzelanie za posiadanie broni bez wymaganych (dwóch nowych) zezwoleń oraz taką samą karę „za ukrywanie zapasów żywności", natomiast za nieposiadanie książeczki pracy lub niewłaściwe albo fałszywe prowadzenie $\mathrm{w}$ niej adnotacji Lenin chciał kar „według praw czasu wojny"16.

O jakimkolwiek postępowaniu śledczym, a tym bardziej sądowym, w dekrecie mowy nie było. Któż więc miał decydować o zastosowaniu, bez śledztwa i sądu oraz odwołania (apelacji), kary śmieci za czyn określony tylko nazwowo? Dekret Ojczyzna socjalistyczna w niebezpieczeństwie nie wymienia, nie wskazuje takiej instytucji, ale została taka wcześniej powołana: to Czerezwyczajka - Czeka.

Tak wróciła oficjalnie kara śmierci do katalogu kar radzieckich; zauważmy, że od wybuchu rewolucji (lutowej) była to już czwarta - w okresie dwunastu miesięcy - decyzja w przedmiocie kary śmierci w ustawodawstwie ${ }^{17}$. I tak utrwaliła się dowolność proceduralno-decyzyjna. W tym trybie rozstrzelana została - to już nieco później - przez Czekę 3 września 1918 r. eserka ${ }^{18}$ Fania Kapłan ${ }^{19}$, która dokonała zamachu na Lenina.

${ }^{16}$ W. Lenin, Dzieła wszystkie..., s. 347-348.

${ }^{17}$ Historia kary śmierci w prawie rosyjskim pierwszego roku rewolucji formalnie przedstawia się tak:

a) 25 III 1917 r. - zniesienie kary śmierci (Rząd Tymczasowy);

b) 25 VII 1917 r. - przywrócenie jej wobec dezerterów na froncie;

c) 28 X/10 XI 1917 r. - zniesienie kary śmierci na zjeździe rad;

d) 21 II 1918 r. - przywrócenie kary śmierci.

Zob. K. Laskowska, Podstawowe zagadnienia instytucji kary śmierci w świetle prawa i praktyki wymiaru sprawiedliwości w dziejach Rosji, [w:] Miscellanea Historico-Iuridica, Białystok 2009, t. VII, s. 56 i n. Z licznymi błędami o karze śmierci zob. też P. H. Juviler, Revolutionary Law and Order. Politics and Social Change in the USSR, New York 1976, s. 25. Por. też A. Lityński, Prawo Rosji i ZSRR 1917-1991 czyli historia wszechzwiazkowego komunistycznego prawa (bolszewików). Krótki kurs, wyd. 2, Warszawa 2012, s. 164-165.

${ }^{18}$ Eserka - członkini partii Socjalistów Rewolucjonistów - SR.

${ }^{19} 30$ VIII 1918 r. Fania [Fanny] Kapłan [właśc.: Fejga Chaimowna Reutblatt] dokonała zamachu na Lenina trafiając go strzałami z rewolweru i raniąc poważnie. Fania Kapłan została bez sądu rozstrzelana przez komendanta Kremla P. Malkowa. Szczegóły sprawy nie 
Później w podobnym trybie - przez rozszerzenie uprawnień trybunałów - aktem niskiej rangi, bo decyzją Ludowego Komisariatu Sprawiedliwości, 16 czerwca 1918 r. zezwolono na stosowanie kary śmierci w postępowaniu przed trybunałami ${ }^{20}$ : trybunały rewolucyjne $\mathrm{w}$ wyborze środków walki z kontrrewolucją nie były związane żadnymi ograniczeniami, poza określeniem ustawy (zakon), iż wymierzać należy karę „nie niżej” niż nakazana (art. 2).

Śledząc dzieje kary śmierci w pierwszym roku rewolucji rosyjskiej dotarliśmy do końca obserwowanego okresu dwunastu miesięcy rewolucji. Wróćmy przeto do bogatego w akty prawne początku bolszewickich rządów w stolicy kraju.

3. Na wieść o obaleniu Rządu Tymczasowego w bolszewickim zamachu stanu najszybciej (26 października/8 listopada 1917 r.) zareagowali Kozacy - negatywnie. W byłym imperium carów Kozacy liczyli około 4,5 mln osób, przy czym 300 tysięcy z nich walczyło w I wojnie światowej; tradycyjnie ludność kozacka trudniła się służbą wojskową. Kozacy mieli silne poczucie odrębności i wewnętrznej spójności (także między oficerami i prostymi żołnierzami). W czasach carskich cieszyli się przywilejami, m.in. mieli prawo tworzenia lokalnych samorządów. W rezultacie byli mniej podatni na hasła rewolucyjne. Słabością kozackich regionów było to, że ich ludność nie była jednolita; znaczna część mieszkańców kozackich regionów nie była bowiem pochodzenia kozackiego i wśród niej hasła rewolucji zyskiwały posłuch, a antybolszewickie działania Kozaków spotykały się z oporem.

Łącznie trzynaście regionów („wojsk”) kozackich miało bronić imperium; część była położona daleko od centrum i ognisk rewolucyjnych; stanice na Syberii nie mogły zagrozić stolicy. Kozacy dońscy pod atamanem generałem Aleksym Kaledinem ${ }^{21}$, Kozacy orenburscy pod atamanem pułkownikiem Aleksandrem Dutowem, Kozacy zabajkalscy pod esaułem Grzegorzem Siemionowem - wszyscy oni natychmiast po otrzy-

zostały wyjaśnione. Dopiero w 1995 r. prokuratura Federacji Rosyjskiej wznowiła śledztwo; wówczas wstępnie ustalono, że do Lenina miał strzelać mężczyzna i wysunięto hipotezę, że Kapłan sama wzięła odpowiedzialność za zamach, a także że była to prowokacja resortu Dzierżyńskiego, poszukującego pretekstu do rozpętania "czerwonego terroru”.

20 Tekst w: История законодательства СССР и РСФСР по уголовному проиессу и организации суда и прокуратуры 1917-1954 г2. Сборник документов, (ред.) С. А. Голунский, Государственное издательство юридической литературы, Москва 1955, s. 46-47; История отечественного государства и права..., s. 81.

${ }^{21}$ Aleksiej M. Kaledin (1861-1918), generał, podczas I wojny światowej dowódca korpusu i armii; w VI 1917 r. wybrany atamanem kozackiego Wojska Dońskiego; po klęsce w walkach z bolszewikami popełnił samobójstwo. Leksykon historii świata: Rosja..., s. 121. 
maniu wieści o bolszewickim zamachu odmówili podporządkowania się nowym w stolicy kraju władzom.

Zbrojnie szybko wystąpił ataman Dutow, a stanica orenburska - położona tam, gdzie Europa styka się z Syberią i Azją Środkową - stała się niezwłocznie aktywnym, choć tak daleko położonym ośrodkiem walki z siłami bolszewickimi. Dutow obalił radę w Orenburgu i przez jakiś czas rozszerzał teren swoich wpływów, jednak niezbyt długo. Wracający $z$ frontu żołnierze kozaccy nie mieli ochoty na dalsze wojowanie, a często byli też zarażeni hasłami i praktyką nieposłuszeństwa wobec władzy, także wojskowej. Nękały Dutowa oddziały zbolszewizowanych robotników, wysyłane często z daleka w trybie „wojny eszelonowej”, a w końcu nie dał rady Północnej Lotnej Kolumnie wojsk bolszewickich; Orenburg został przez nich zdobyty (31 stycznia 1918 r.), a sam ataman z nieliczną już garstką wiernych żołnierzy zepchnięty na tereny południowego Uralu, a wiosną 1918 r. na stepy kazachskie ${ }^{22}$.

Najważniejszy był jednak obwód wojska dońskiego. Stanica dońska to obszar o powierzchni większej niż Anglia, liczba zaś tamtejszych Kozaków sięgała ponad 1,5 mln. Terytorium wojska dońskiego to Europa, położenie stanicy było strategiczne: blisko Ukrainy i zagłębia węglowego Donbas, największe miasta nad Donem - Nowoczerkask i Rostów leżały na szlaku kolejowym łączącym Rosję z Kaukazem. Istotne jest to, że wybrany pół roku wcześniej atamanem Aleksiej Kaledin miał duże doświadczenie wojskowe: wszak był generałem na froncie wojny światowej.

Kaledin już w dniu zwycięskiego dla bolszewików przewrotu ogłosił przejęcie przez nich władzy za przestępcze i w imieniu własnym oraz „w ścisłym powiązaniu z rządami pozostałych wojsk kozackich" zadeklarował pełne poparcie dla Rządu Tymczasowego. Stojący na czele Rządu Wojskowego Kaledin już 26 października/8 listopada 1917 r. wystosował na ręce Kiereńskiego zaproszenie dla całego Rządu Tymczasowego do przybycia do Nowoczerkaska - stolicy Kozaków dońskich ${ }^{23}$. Tak szybka reakcja na zamach i kategoryczne stanowisko zyskały Kaledinowi rozgłos w całej Rosji. Wszak było to w tym momencie jedyne mogące się liczyć ognisko oporu wobec zwycięskich zamachowców w stolicy. Toteż do Nowoczerkaska ściągali politycy i wojskowi wobec bolszewików opozycyjni, chociaż niekoniecznie o wspólnym zabarwieniu politycznym; najwięcej było tych z prawej strony sceny politycznej, czyli m.in. kadetów. Już w tydzień (2/15 listopada 1917 r.) po obaleniu Rządu Tymczasowego w Nowoczerkasku zjawił się generał Michał Aleksiejew, były wódz na-

${ }^{22}$ E. Mawdsley, Wojna domowa w Rosji 1917-1920, tłum. M. Popławska, Warszawa 2010, s. 37.

${ }^{23}$ R. Wojna, W ogniu rosyjskiej wojny wewnętrznej 1918-1920, Warszawa 1975, s. 29-30. 
czelny z okresu Rządu Tymczasowego, a wcześniej dowódca frontu i szef sztabu naczelnego wodza Mikołaja II. Nie bez obiekcji kozacki Rząd Wojskowy potwierdził stosowną decyzję o utworzeniu armii i zatwierdził nazwę Armia Ochotnicza. Jak wspominał generał Denikin, na propozycję Borysa Sawinkowa Armia Ochotnicza ogłosiła w deklaracji, że celem jest zrzucenie jarzma „niemiecko-bolszewickiego” oraz zwołanie Zgromadzenia Ustawodawczego ${ }^{24}$. W kilka tygodni później (6/19 grudnia) przybył do Nowoczerkaska generał Ławr Korniłow, także krótko były wódz naczelny z tygodni letnich Rządu Tymczasowego, słynny z nieudanego puczu i później drugiej już ucieczki z więzienia (chociaż tym razem znacznie łatwiejszej).

Równie szybka była reakcja przewodniczącego Rady Komisarzy Ludowych - Lenina, który napisał, a Rada Komisarzy Ludowych 28 listopada/11 grudnia 1917 r. uchwaliła Dekret o aresztowaniu przywódców wojny domowej przeciw rewolucji $i^{25}$. Bezpośrednią przyczyną stworzenia tego dekretu była demonstracja, a nawet naiwna próba puczu w wykonaniu kadetów (konstytucyjnych demokratów), którzy po demonstracji ulicznej próbowali doprowadzić do zainicjowania przez Zgromadzenie Konstytucyjne obrad. Na mocy dekretu "podlegają aresztowaniu i oddaniu pod sąd trybunałów rewolucyjnych" aktywni członkowie partii kadetów, "jako partii wrogów ludu". Na rady w terenie dekretem nałożony został natomiast "obowiązek szczególnego nadzoru nad partią kadetów z powodu jej powiązania z korniłowsko-kaledinowską wojną domową przeciw rewolucji". Dekret wchodził w życie z chwilą podpisania ${ }^{26}$. To jeden z pierwszych aktów prawnych nowej władzy w Piotrogrodzie, który zawierał normy prawnokarne. Później jeszcze pojawi się dekret $O$ walce $z$ kontrrewolucyjnym powstaniem Kaljedina, Korniłowa, Dutowa i inne. Dokumenty te jednak bardziej przypominały odezwy polityczne aniżeli akty prawne, w szczególności nie zawierały żadnej nawet próby typizowania czynów zabronionych, w zakresie zaś środków karnych z reguły ograniczały się do sformułowania, że „podlega surowemu ukaraniu”" ${ }^{27}$.

4. Skoro Dekret o aresztowaniu przywódców wojny domowej przeciw rewolucji przewidywał oddanie ich pod "sąd trybunałów rewolucyjnych", przeto trzeba $\mathrm{w}$ tym miejscu zająć się trybunałami, w szczególności zaś ustaleniem, jakie kary mogły one nakładać na „wrogów ludu” oraz „kontrrewolucjonistów”, na których czele stała partia kadetów. Takie określenia wszak znalazły się w powoływanym dekrecie oraz w uzupeł-

\footnotetext{
${ }^{24}$ Za R. Pipes, Rosja bolszewików, tłum. W. Jeżewski, Warszawa 2005, s. 18.

${ }^{25}$ W. Lenin, Dzieła wszystkie..., s. 121 i 448.

${ }^{26}$ Tamże, s. 121.

${ }^{27}$ M. Filar, W stużbie utopii..., s. 12.
} 
niającej dekret rezolucji Centralnego Komitetu Wykonawczego z 1(14) grudnia $1917 \mathrm{r}^{28}$ To brzmiało złowieszczo.

Pierwszym aktem prawnym odnoszącym się do ustroju sądów i innych organów funkcjonujących $\mathrm{w}$ związku $\mathrm{z}$ wymierzaniem sprawiedliwości był dekret nr 1 o sądzie z 24 listopada/7 grudnia 1917 r. ${ }^{29}$ Stanowił likwidację dotychczasowych instytucji wymiaru sprawiedliwości i powoływał dwa rodzaje sądów bolszewickich, a mianowicie: 1) sądy lokalne (ludowe), 2) trybunały rewolucyjne. Trybunały rewolucyjne ustanowione zostały "do walki z siłami kontrrewolucyjnymi i ochrony przed nimi rewolucji" Reorganizacja sądów przewidziana w dekretach nr 2 i 3 o sądzie nie odnosiła się do trybunałów rewolucyjnych, które nietknięte funkcjonowały obok sądów ludowych, a nawet wkrótce zostały rozbudowane. Był to odrębny system sądów, istniejący równolegle do sądów ludowych. Powstawały żywiołowo w jednostkach wojskowych, w stolicy, w terenie. Jak gdyby w rozwinięciu nad wyraz lakonicznego unormowania w dekrecie nr 1 o sądzie, Ludowy Komisariat Sprawiedliwości RSFRR (Ludowy Komisarz Sprawiedliwości eserowiec Izaak Zacharewicz Szteinberg [Steinberg]) wydał 19 grudnia 1917 r. (1 stycznia 1918 r.) Instrukcję dla trybunałów rewolucyjnych ${ }^{30}$, regulującą ich skład osobowy, kompetencje, procedurę (fragmentarycznie), wymierzane kary. W katalogu kar znalazły się: praca poprawcza, pozbawienie wolności, zsyłka i wysyłka, kara pieniężna, całkowity lub częściowy przepadek mienia, ogłoszenie wrogiem ludu, pozbawienie praw politycznych; Instrukcja nie zawierała kary śmierci ${ }^{31}$.

W czerwcu 1918 r. Ludowy Komisariat Sprawiedliwości RSFRR [LKS] poinstruował, że trybunały rewolucyjne nie są niczym ograniczone w wyborze środków walki z kontrrewolucją, sabotażem itp. z wyjątkiem tych przypadków, kiedy ustawa określa dolną granicę kary - górnej granicy ustawowej trybunał nie musiał przestrzegać ${ }^{32}$. Dalsze reorganizacje trybunałów rewolucyjnych przeprowadzano $\mathrm{w}$ następnych miesiącach i latach wojny domowej ${ }^{33}$. Obok nich zaś funkcjonowały jeszcze sądy wojskowe oraz administracyjny tryb orzekania kar i stosowania innych represji, a zwłaszcza sądy organu administracyjnego, jakim była Czeka-

${ }^{28}$ W. Lenin, Dzieła wszystkie..., s. 134.

${ }^{29}$ Tekst m.in. История законодательства..., s. 31-32; История советской конституиции (в документах) 1917-1956, Москва 1957, s. 69-71; История советской конституции. Сборник документов. 1917-1957, Москва 1957, s. 28-30.

${ }^{30}$ История законодательства..., s. 34-36

${ }^{31}$ Tamże, s. 34-36; M. Filar, W stużbie utopii..., s. 13; zob. też S. Ciesielski, GUŁag. Radzieckie obozy koncentracyjne 1918-1953, Warszawa 2010, s. 27-28.

${ }^{32}$ История законодательства..., s. 46-47.

${ }^{33}$ Zob. zwłaszcza tamże, s. 83-86. 
-GPU-OGPU. W tych ostatnich organach, bez żadnej podstawy prawnej, sądziły na szczeblu centralnym komisja administracyjna, zmieniona w 1923 r. w kolegium sądowe OGPU, w terenie zaś tzw. trojki.

5. W tym momencie warto bardzo krótko przypomnieć historię narodzin i rolę policji politycznej. Skoro jednak w niniejszym tekście dokonujemy rocznego bilansu rosyjskiej rewolucji (od marca 1917 do marca 1918 r.), to należałoby jeszcze krócej cofnąc się do rewolucji obalającej carat. Carska Ochrana ${ }^{34}$ została zlikwidowana faktycznie podczas rewolucji lutowej: już 27 lutego/12 marca 1917 r. do gmachu Ochrany - Departamentu Policji przy Fontance $16 \mathrm{w}$ Piotrogrodzie - wtargnął tłum, co oznaczało koniec tej instytucji. W kilka dni później uzbrojeni ludzie zajęli budynek Ochrany w Moskwie, zniszczyli archiwa ${ }^{35}$, zrabowali kasę. Wkrótce uwięziono naczelnika Ochrany. Rząd Tymczasowy niezwłocznie po objęciu władzy rozwiązał Departament Policji oraz Korpus Żandarmów, a dla wykonywania codziennych zadań policyjnych powołał milicję obywatelska, formację niezawodowa, ochotniczą. Niewyszkolona milicja absolutnie nie była w stanie podołać oczekiwaniom; w stolicy zapanowała anarchia ${ }^{36}$.

Warto przypomnieć, że Lenin $\mathrm{w}$ tzw. tezach kwietniowych (w kwietniu 1917 r.) pisał, że po rewolucji proletariackiej nie będzie zawodowej policji ani wojska ${ }^{37}$. Natomiast po zamachu październikowym 1917 r. rozmiar wewnętrznej i zewnętrznej opozycji wobec bolszewików przekroczył wyobrażenia Lenina - w Zgromadzeniu Konstytucyjnym większość zdobyli socjaliści-rewolucjoniści (eserowcy), bolszewicy mieli w nim około $24 \%$ miejsc. Na 19 grudnia zapowiedziano strajk pracowników państwowych. Chaos był pełny, a władza bolszewików dość nominalna i w zasadzie nie wykraczała poza stolicę. Siły przeciwne uważały rząd bolszewicki za efemeryczny, przejściowy w absolutnym chaosie rosyjskiego państwa. Sytuacja bolszewików wydawała się niemal beznadziejna. W kraju politycznie silniejsi od nich byli eserowcy, w tym lewicowi eserowcy; silni byli monarchiści. W 1918 r. (9 marca) w Murmańsku wylądowało 200 angielskich żołnierzy,

\footnotetext{
${ }^{34}$ Ochrana - carska tajna policja polityczna powołana w 1881 r. (po zabójstwie cara Aleksandra II) jako Wydział dla Ochrony Porządku i Bezpieczeństwa Publicznego; podporządkowana ministrowi spraw wewnętrznych.

${ }^{35}$ Do dzisiaj nie ma pewności, czy byli to rewolucjoniści, czy też tajni agenci i współpracownicy policji, którzy chcieli zniszczyć kompromitujące i niebezpieczne dla nich materiały, Ch. A. Rud, S. A. Stiepanow, Strach. Tajna policja carów, tłum. M. Przeczek, Warszawa 2001, s. 433.

${ }^{36}$ Tamże, s. 434.

${ }^{37} \mathrm{~W}$. Lenin, O zadaniach proletariatu w obecnej rewolucji (tezy kwietniowe), [w:] W. Lenin, Dzieła wybrane, t. II, Warszawa 1978, s. 207-212; toż w: S. Žižek, Rewolucja u bram. Pisma Lenina z roku 1917, tłum. J. Kutyła, Kraków 2006, s. 123-131.
} 
a później piechota amerykańska; we Władywostoku japońska, a potem też amerykańska. Te obce siły były niewielkie i nie miały w programie agresji wobec republiki rosyjskiej, lecz celem ich było zabezpieczenie strategicznych punktów i ewentualnie składów broni i amunicji przed możliwym zdobyciem ich przez Niemców. Biała Armia zdobyła Archangielsk. Korpus Czechosłowacki (50 tysięcy dobrze wyszkolonych i uzbrojonych żołnierzy) przywódcy czechosłowaccy oddali do dyspozycji Ententy.

Stosowanie terroru wobec opozycji było mocno obecne w programie Lenina. W reakcji na strajki urzędników i bojkot przez nich nowych władz, w reakcji na zaplanowaną przez kadetów demonstrację (28 listopada/ 11 grudnia 1917 r.), dla przygotowywanej bolszewickiej kontrdemonstracji wśród haseł bolszewickich Lenin osobiście napisał: „Precz z sabotażystami i strajkującymi urzędnikami! Bojkot i rewolucyjny terror wobec nich!"38 Jak już wspomniano, tego samego dnia Lenin napisał, a RKL uchwaliła dekret o aresztowaniu i oddaniu pod sąd trybunałów rewolucyjnych kadetów. Wobec oporu urzędników, wobec bojkotowania przez nich zarządzeń władz bolszewickich, na posiedzeniu RKL 6(19) grudnia 1917 r. polecono Dzierżyńskiemu utworzenie komisji do opracowania sposobów walki z tym zjawiskiem. Nazajutrz Dzierżyński już referował sprawę na posiedzeniu RKL, Lenin zaś przesłał mu notatkę z propozycją dekretu $O$ walce $z$ kontrrewolucjonistami i sabotażystami ${ }^{39}$. W takiej sytuacji 7(20) grudnia 1917 r. zapadła decyzja Rady Komisarzy Ludowych o powołaniu do życia „organu dyktatury proletariatu dla ochrony bezpieczeństwa państwowego Republiki Radzieckiej". Otrzymał on nazwę - Nadzwyczajna Komisja do Walki z Kontrrewolucją, Spekulacją i Przestępstwami (od sierpnia 1918 r.: Wszechrosyjska...) [Чрезвычайная Комиссия по Борьбе с Контрреволюцией, Спекуляцией и Преступлениями ${ }^{40}=$ Czerezwyczajnaja Komisja po Bor'bie s Kontrriewolucyjej, Spekuljacijej i Priestuplenijami], stąd popularny skrót: Czerezwyczajka albo jeszcze krócej: Czeka. W późniejszym referacie Dzierżyński na posiedzeniu Wszechrosyjskiego Centralnego Komitetu Wykonawczego zwrócił uwagę, że „Utworzenie WCzK zbiegło się z rozwiązaniem Piotrogrodzkiego Komitetu Rewolucyjnego, WCzK powstała zatem w momencie, gdy nie było organu, który by podjął walkę z kontrrewolucją, sabotażem i spekulacją. Uchwałą Rady Komisarzy Ludowych z dnia 7 [20 - A. L.] grudnia 1917 r. zostało zatwierdzone Kolegium WCzK do bezwzględnej walki z kontrrewolucją" ${ }^{41}$.

${ }^{38}$ W. Lenin, Dzieła wszystkie, t. III, Warszawa 1988, s. 120.

${ }^{39}$ Tamże, s. 152-154.

${ }^{40}$ Dokładnie taką nosiła nazwę; bywa ona w wielu publikacjach nieco zniekształcana. Zob. dokumenty tego czasu История законодательства..., s. 64, 185.

${ }^{41}$ F. Dzierżyński, Pisma wybrane, Warszawa 1951, s. 227. 
Dopiero w rok później (28 października 1918 r.) dekret Wszechrosyjskiego Centralnego Komitetu Wykonawczego ${ }^{42}$ wyraźnie stanowił, że Czeka jest organem Rady Komisarzy Ludowych (rządu) i RKL powołuje członków Komisji. Jednocześnie powiązano (luźno) Czerezwyczajkę z Ludowym Komisariatem Spraw Wewnętrznych (NKWD) oraz Ludowym Komisariatem Sprawiedliwości (NKJ). Za deklaracja, że Czeka ma "ś́ciśle" współpracować z NKWD i NKJ poszedł przepis, że przewodniczący Czeki zostaje włączony do kolegium NKWD, przedstawiciele zaś NKWD i NKJ delegowani są do Czeki. Nie było tu jednak żadnego podporządkowania. W terenie dekret przewidywał lokalne komisje powoływane przez rady albo ich komitety wykonawcze.

Czeka nie miała wyraźnie określonych kompetencji, toteż wykonywała wszelakie zadania realizujące terror, $\mathrm{z}$ aresztowaniami, przesłuchaniami i egzekucjami. Żadna procedura nie była do tych czynności przypisana.

Nie wystarczało, że Czeka uzyskała praktycznie nieograniczone pełnomocnictwa. Fala anarchicznych, „dzikich” morderstw zalała kraj; mordowano inteligencję. Czeka wykonywała terror zdyscyplinowany. Za zamordowanie Mojsieja Urickiego rozstrzelano w Piotrogrodzie 500 zakładników. Za powstanie w Jarosławiu - 400. Egzekucje przy użyciu pistoletu i karabinu nie były dość wydajne. Dzierżyński wydał rozkaz, by używano karabinów maszynowych. W Piotrogrodzie wydawano tak wiele wyroków śmierci, że skazanych wiązano parami, ładowano nocami na drewniane barki, które wyprowadzano na wody Zatoki Fińskiej, za latarnię Tołbuchina, i tam zatapiano; gdy wiał zachodni wiatr - to ciała później wpływały do portu w Kronsztadzie ${ }^{43}$.

6. Radzieccy uczeni wyrazili pogląd, że szybkie wydanie dość licznych aktów prawa karnego „dało możność organom wymiaru sprawiedliwości kierowania się jedynie dekretami rzadu robotniczego $i$ chtopskiego $i$ sumieniem socjalistycznym (art. 3 dekretu o sadzie nr 3)" ${ }^{\prime 4}$. Wszelako były to akty prawa terroru, na czele z dekretem Ojczyzna socjalistyczna w niebezpieczeństwie, którym Czeka otrzymała nieograniczone prawo zabijania ludzi według swojego uznania, bez żadnej procedury. Wydany niemal dokładnie $\mathrm{w}$ rok po wybuchu rewolucji dekret stanowi, przynajmniej w materii prawa karnego, podsumowanie pierwszego okresu zdobywania władzy przez bolszewików.

${ }^{42}$ Tekst w История законодательства..., s. 64.

${ }^{43}$ A. Lityński, Prawo Rosji i ZSRR 1917-1991 czyli historia wszechzwiazkowego komunistycznego prawa (bolszewików). Krótki kurs, Warszawa 2010, s. 325 i n.

${ }^{44}$ W. Mienszagin, Z. Wyszynska, Radzieckie prawo karne, Warszawa 1953, s. 16. 


\section{Bibliografia}

\section{Źródła}

Dzierżyński F., Pisma wybrane, Warszawa 1951.

Historia państwa i prawa. Wybór tekstów źródłowych, red. B. Lesiński, Poznań 1995.

Lenin W., Dzieła wszystkie, t. III, Warszawa 1988.

Lenin W., Dzieła wszystkie, t. XXXV, Warszawa 1988.

Lenin W., O zadaniach proletariatu w obecnej rewolucji (tezy kwietniowe), [w:] tenże, Dzieła wybrane, t. II, Warszawa 1978.

Lenin W., O zadaniach proletariatu w obecnej rewolucji (tezy kwietniowe), [w:] S. Žižek, Rewolucja u bram. Pisma Lenina z roku 1917, tłum. J. Kutyła, Kraków 2006.

Об отмене смертной казни, СУ РСФСР 1917, nr 1.

Trocki L., Moje życie. Próba autobiografii. Autoryzowany przekład z rosyjskiego J. Barski i S. Łukomski, Warszawa 1930 [reprint: Warszawa 1990].

\section{Opracowania}

Ciesielski S., GUŁag. Radzieckie obozy koncentracyjne 1918-1953, Warszawa 2010.

Encyklopedia biatych plam, t. XVI, Radom 2005.

Filar M., W stużbie utopii. 73 lata radzieckiego prawa karnego, Toruń 1992.

Historia wszechzwiązkowej komunistycznej partii (bolszewików). Krótki kurs, Warszawa 1948.

История отечественного государства и права, част 2, четвертое издане, переработанное и дополненное, авторский коллектив под редакцией О. И. Чистякова, Москва 2006.

История советской конституцции. Сборник документов. 1917-1957, Москва 1957. История законодательства СССР и РСФСР по уголовному процессу и организации суда и прокуратуры 1917-1954 г2. Сборникдокументов, (ред.) С. А. Голунский, Государственное издательство юордической литературь, Москва 1955.

Juviler P. H., Revolutionary Law and Order. Politics and Social Change in the USSR, New York 1976.

Kowalczyk A. S., Sawinkow, Warszawa 1992.

Laskowska K., Podstawowe zagadnienia instytucji kary śmierci w świetle prawa i praktyki wymiaru sprawiedliwości w dziejach Rosji, [w:] Miscellanea Historico-Iuridica, Białystok 2009, t. VII.

Leksykon historii powszechnej 1900-1945, red. S. Sierpowski przy współpracy S. Żerki, Poznań 1996.

Leksykon historii świata: Rosja, red. W. Sienkiewicz, Warszawa 2001.

Lityński A., Prawo Rosji i ZSRR 1917-1991 czyli historia wszechzwiazkowego komunistycznego prawa (bolszewików). Krótki kurs, Warszawa 2010.

Lityński A., Prawo Rosji i ZSRR 1917-1991 czyli historia wszechzwiązkowego komunistycznego prawa (bolszewików). Krótki kurs, wyd. 2, Warszawa 2012.

Lityński A., Utworzenie naczelnego organu administracji państwowej RFSRR - Rady Komisarzy Ludowych, „Gdańskie Studia Prawnicze” 2012, t. XXVII: W kręgu historii doktryn politycznych i prawnych oraz konstytucjonalizmu. Ksiega jubileuszowa Profesora Andrzeja Sylwestrzaka, red. D. Szpoper. 
Mawdsley E., Wojna domowa w Rosji 1917-1920, tłum. M. Popławska, Warszawa 2010.

Mienszagin W., Wyszynska Z., Radzieckie prawo karne, Warszawa 1953.

Pipes R., Rosja bolszewików, tłum. W. Jeżewski, Warszawa 2005.

Przebinda G., Smaga J., Kto jest kim w Rosji po 1917 roku, Kraków 2000.

Rud Ch. A., Stiepanow S. A., Strach. Tajna policja carów, tłum. M. Przeczek, Warszawa 2001.

Стучка П., Эничиклопедия государтва и права, t. II, Москва 1930.

Urbankowski B., Józef Piłsudski - marzyciel i strateg, Poznań 2014.

Wieczorkiewicz P. [w:] L. Bazylow, Historia Rosji, Wrocław-Warszawa-Kraków 2005.

Wielka encyklopedia powszechna PWN, t. I-XIII, Warszawa 1963-1970.

Wojna R., W ogniu rosyjskiej wojny wewnętrznej 1918-1920, Warszawa 1975. 